\title{
Group Work in the Secondary ESL Classroom
}

\author{
Gopala Krishnan Sekharan Nair ${ }^{1}$, Rozlan Abdul Rahim ${ }^{1}$, Aileen Farida binti Mohd Adam ${ }^{1}$, Roszainora Setia ${ }^{1}$, \\ Norhayati Husin ${ }^{1}$, Elangkeeran Sabapathy ${ }^{1}$, Razita Mohamad ${ }^{1}$, Shahidatul Maslina Mat So’od ${ }^{1}$, Nurul Izatee Md \\ Yusoff $^{1}$, Razifa Mohd Razlan ${ }^{1}$, Nur Amalia Abd Jalil ${ }^{1}$, Uzah Alwee ${ }^{2}$ \& Norhafiza Abu Seman ${ }^{3}$ \\ ${ }^{1 .}$ Academy of Language Studies, Universiti Teknologi MARA, Dungun, Malaysia \\ ${ }^{2}$ Balai Besar Secondary School, Dungun, Malaysia \\ ${ }^{3}$ Faculty of Administrative Science and Policy Studies, Universiti Teknologi MARA, Dungun, Malaysia \\ Correspondence: Gopala Krishnan Sekharan Nair, Academy of Language Studies, Universiti Teknologi MARA, \\ 23000 Dungun, Terengganu, Malaysia. E-mail: gopal792@tganu.uitm.edu.my
}

Received: January 2, 2012 Accepted: February 27, $2012 \quad$ Published: August 1, 2012

doi:10.5539/ass.v8n10p3

URL: http://dx.doi.org/10.5539/ass.v8n10p3

\begin{abstract}
This study involves a survey on student's perceptions on whether group work is enjoyable, interesting, promotes interaction and an effective mechanism of learning. It further investigated if gender and performance in English had any bearing on group work. The instrument used consisted of four sections. Section A is for the descriptive data, while section B, C and D use a Likert scale where ' 5 ' was the most positive answers. The sample of 70 respondents was randomly chosen from a semi urban school in the East Coast state of Terengganu. There were 27 males and 43 females and all of them were 16-year-old Malay Form Four students. The findings indicated that the students found group work to be enjoyable, interesting and promoted interaction. They also perceived it to be an effective means of learning. Through comparison of means and t-testing, it was established that there was no significant different between the genders in their inclination towards group work. Co-relational analysis indicated that there was no significant relationship between the students English language performance in their keenness towards group work. For future research, the study should be conducted in a longer period and in experiential way.
\end{abstract}

Keywords: group work, group activities, classroom, ESL (English as Second Language)

\section{Introduction}

In recent years, one of the basic problems in teaching English as a second language is to prepare those students to be able to use the language. The reasonable command of English language would enable them to get information and also give out information accurately. The students' proficiency in English as a second language (ESL) can be improved through the practice of writing and speaking skills. In addition, most of the teaching and learning process is class centered, whereby students only listen to their teachers as instructors who only enhance their commands. Some teachers feel that the best way to teach language is through whole class teaching. There are many benefits for using group work in the ESL classroom but not many teachers use this strategy. They seem to feel that group work is difficult to carry out. Many teachers think that group work consumes more time. Sometimes, the students will start to use their mother tongue to express an idea when they get excited and they won't talk in English Galton et.al. (1980). As a teacher, we need to help students take appropriate responsibility for their success and failure and encourage them to set realistic and short term goals. Doyle (1986), states that he viewed the classroom as a unique unit in which the teachers and their students interact for the purpose of teaching and learning to take place.

The present study will focus on the students' perception in group work activities in the ESL class room and to find out whether group work activities will make the learning of English interesting and enjoyable. It also seeks to find out whether group work activities can promote interaction among teammates and to look into whether group work is also an effective learning mechanism according to students' perception. Likewise, this study also compares the significant relationship between the PMR grade and the tendency to find group work interesting and enjoyable. The researcher will also look into whether girls find group work to be more interesting and enjoyable than boys.

This particular study focuses on the group work activities of Form Four students in one of the secondary schools in Dungun, Terengganu. This research was carried out regarding the group work activities in ESL classroom. 


\subsection{Literature Review}

In Malaysia, mixed ability classes have been the norm in both primary and secondary schools for many years, usually groups of students numbering more than forty are put together in a classroom. These students are different in terms of intellectual ability, cultural experiences, interests, and attitude rates of learning. As a result of these differences, it is simply impossible to successfully teach all the students in exactly the same way at the same time.

Richard and Nunan (1987), stated that group work provides opportunities for children to talk freely, and it is generally accepted that this improves their language. To increase the amount of practice of each student, the class needs to be divided into groups and given ample practice through relevant and realistic language activities. Slavin (1990), has shown that working in mixed-ability teams can benefit both higher and lower achieving students in many subject areas. Group work in teaching can help students to develop particular skills. Jacques (1991), further stated that when teachers make students work in small groups, students are offered safely to take risks in trying and testing new behavior.

The Integrated Secondary School Curriculum (KBSM) on the other hand also encourages teachers to use a range of teaching strategies that will stimulate active involvement in the lesson. According to Good, T.et.al (1994), there is growing interest in the potential of cooperative small groups for helping students to learn more actively and for ameliorating differences among students in classroom interaction and participation. In addition, teachers can help to make group work more meaningful by explaining the task and allowing students to actively discuss its purpose and related procedures before moving into small groups. Blumenfeld (1992), noted that even though students found small-group work more motivating and enjoyable, active learning declined during small-group work. Thus, group work is considered an essential approach for teaching mixed ability classes.

Classroom management involves changing the social environment of the classroom from one-way teacher centered situation to that of a co-operative and participating learning situation. Group work is certainly part of classroom management as it involves teachers having to organize and manage groups and in addition to it they have to cater for wide range of abilities and attainments. Most probably there is greater demand on the teacher of mixed ability classes because then it would require the teacher to form groups which can work well together.

Group work allows for differentiation of tasks at the same time. These differentiated groups as suggested by Stradling and Saunders (1993), can be formed formed to match learning targets, task, activities, resources, and different learning styles. Group can be formed to match students' ability or interest. As a result of this, nowadays schools use a combination of grouping. Nunan (1991), has proposed a few guidelines that teachers should be aware of when in the process of forming groups such as: kind of grouping, size of grouping, lay-out of furniture, and seating arrangement. It is said that a good working group channels a sense of achievement. Therefore, various qualities such as tolerance, team spirit, giving and taking, establishing a direction in learning, developing imaginative and creative thinking, developing a critical and informed mind, developing an ability and sense of enjoyment in life -long learning are also brought forth by group work.

It is imparity that educational and curriculum planners in Malaysia give serious thought to the implementation of group work in the classroom. In the KBSM curriculum, which was in existence some years ago, group work was prescribed. However, the KBSM curriculum did not meet with the success that was expected. In order to overcome the mix ability classes' problem, groups can be formed according to skills, interest, ability, achievement, purpose for tasks and selection of materials. Putting students who can work well together will have an effect on the task completion and the amount of interaction that occurs. The fact is teachers should be aware of the various kinds of groups according to the purpose of the task.

In addition, teachers have identified a number of problems, which they associate with group work and therefore, consider being disadvantages. First, many teachers appear concerned about motivating the children and helping them to recognize that being in a group is for the purpose of work rather than a chance to chat and just 'have fun'. According to Sellaodayan (1988), motivation is vital for any productive learning outcome. However, the monitoring of group work can pose problems, especially if the group is distended to work collaboratively on their own without a teacher. Furthermore the management of groups, in terms of such issues as who should be in the group, how many children and where they should work, may pose difficult dilemmas which have to be resolved.

\subsection{Methodology}

This is a quantitative exploratory study involving descriptive and referential statistics to elicit responses from students regarding group works. The method involved a four -sections of questionnaire to be answered by the respondents which were randomly chosen suggested by Jaccard and Becker (1990). Seventy respondents out of 150 Form Four students of a semi-urban secondary school in Dungun, Terengganu were taken as the sample. 
Section A of the questionnaire was to gather the demographic profile of the respondents comprising information of their gender, age, race, parents or guardians occupation and their English grade for their PMR examination. Sections B, C and D comprised 10 questions each and Likert scale was used as the benchmark. Section B was aimed at finding out whether students found that group work activities provide interesting and enjoyable lesson, while Section C aimed at finding out whether students found that group work activities promote interaction among teammates. In addition, Section D was to find out whether students found that group work is an effective learning mechanism.

Descriptive statistic such as mean, median and mode will be used to answer the first three research questions, whereas for the last research question, inferential statistic will be used. The correlation between the two variables under investigation will be found. A comparison of means and a T-test will be accomplished to see whether there is a significant relationship between the PMR grade and the tendency to find group work interesting and enjoyable.

Data collection: This study will attempt to find out whether group work activities can provide interesting and enjoyable lessons, to find out whether group work activities can promote interaction among teammates, to look into whether group work is also an effective learning mechanism according to students' perception and to compare the significant relationship between the PMR grade and the tendency to find group work interesting and enjoyable. At the same time, the researcher will also look into whether girls find group work to be more interesting and enjoyable than boys.

\section{Results and Discussion}

\subsection{Group Work Activities Provide Interesting and Enjoyable Lesson}

The findings showed that teaching ESL using group work activities made the lessons more interesting and enjoyable as it reduced the tediousness of language lessons. He further added that group work is superior to exercises such as classroom drills as it provides opportunities for children to talk freely as they find group work activities to be interesting and enjoyable, and this helps to improve their language.In view of this, school teachers should pay careful attention to the value of group work in the ESL classroom as well as give motivation to their students as the performance improves substantially when they are enjoying their lessons and highly motivated.

If group work fails to yield the expected results, teachers must look into the management of the group work rather then attribute the shortcoming to that of group work itself.

\subsection{Group Work Activities Promote Interaction among Teammates}

This study found that group work activities managed to promote interaction among teammates. By putting students in groups, teachers will give more language practice to the students. As students are more involved, they will feel secure and help each other to complete the tasks.

Additionally, working in mixed-ability teams can benefit both higher and lower achieving students in many subject areas. What this means for the classroom practitioner is that group work is certainly a viable and the valuable tool in the teaching and the learning of English. One of the many complaints against the graduate of the public universities is that they lack communicative skills and may pose a liability to the corporate image of an organization with their sub-standard command of English. Thus, training the students in communicative competency must start while they are still at school. Towards this end, the findings of this research show that group work activities are a valuable tool.

\subsection{Group Work as an Effective Learning Mechanism}

This study also found that group work activities are an effective learning mechanism as perceived by the students. It is evident that the student client is satisfied with group work being an effective tool of learning.

The students' opinion on this matter should not be lightly dismissed. As being at the receiving end of the classroom learning process, they are in the best position to decide which pedagogy results in the highest amount of added value.

\subsection{Girls Find Group Work to Be Interesting and Enjoyable than Boys}

According to the finding, it is indicated that there is no difference between girls and boys when it comes to interest in group work activities. This finding was included to provide information to assist the teacher in customizing the pedagogy according to the students.

This finding shows that group work is equally favored by both genders, and no one group was found more suitable for group work compared to the other. Therefore, educators may freely administer group work to either gender. In 
the event of ineffectiveness of the group work, what must be looked into is group management rather then the gender of the group members. Gender must not be made a scapegoat for any weakness in group work management.

\subsection{The Significant Relationship between the PMR Grade and the Tendency to Find Group Work Interesting and} Enjoyable

The study shows that there is no significant relationship between the PMR grade and the tendency to find group work enjoyable. This finding is also included to throw light on factors that might have a bearing on the learners' attitude towards group work. The differentiated groups can be formed to match learning targets, task, activities, resources, and different learning styles, as well as students' ability or interest.

Therefore, the students' performance on English language is not an issue when carrying out group work. Whether they are weak students or competent ones, the tasks can actually be tailored made to match the group's activities. In fact, weaker students actually benefit from group work. Student ability is not a problem while doing group work. When students work in groups, the weaker students especially, were encouraged and motivated by their teammates to discuss together and contribute ideas towards the exercises. Hence, they would feel that they are not neglected. It would increase their self-esteem, confidence and interest in learning English. Educators must not attribute any failure in group work to the students' ability level. Rather, the management of the group by the teacher should be inspected.

\subsection{Suggestions and Recommendations}

In view of the value of group work, it must be an important part in the repertoire of any teachers' pedagogy. Teacher training curriculum must include group work management since the value of group work in the ESL classroom is backed by research.

In discussing on the issue of group work, Robiah Sidin (1993), once claimed that groups are actually formed because members need to come together to get something done or to produce something using knowledge and skills. By being members of the group, the students think that they can be moreore productive and successful in their efforts.

In doing group work, there is probably a greater demand on the teacher of mixed ability classes because then it would require the teacher to form groups which can work well together. Therefore, aspiring teachers must be made aware that group work is not merely the breaking up of the class randomly into smaller groups. In the KBSM curriculum sometimes ago, it was found that group work did not always produce the expected results. As there is a body of evidence supporting group work, the failure of KBSM must not be cited to discount group work as a valuable tool of learning. Thus, teachers need to provide a variety of learning activities as the changes in instructional activities help students to pay attention and renew interest. The low achievement students need more varieties to avoid boredom. Therefore, we should help students to take appropriate responsibility for their success and failure and encourage them to set realistic and short term goals Orstein and Thomas (2000).

Kerry and Sands (1982), proposed that random task be matched to mixed ability groups, the tasks planned should cater for different groups in the class and set accordingly to meet the different ability of the group or a combination of all the aforementioned. Teacher training curriculum planners should be aware that carrying out classroom group work requires professional competency and does not means the mere division of a class into smaller units. Training teachers should undergo in group management skills to upgrade their teaching competency.

At the state level, the state education department should organize courses for teachers where they can be trained by experts on proper group work management. At the school level, the heads of department should hold regular sessions to instill in teachers, group practices in carrying out group work.

It is hoped that this study will give future researchers to do further studies and focus on the problems encountered in group work activities in mix ability ESL classroom.

\section{Conclusion}

English language is very important to our nation, in this era of globalization. Therefore, it is imperative that every means be found to strengthen the English language competency of our students. English language pedagogy must be upgraded and made more effective. Towards this end, the viability of group work in the classroom must not be discounted.

The teachers must approach group work with skill and competence. They should be trained in the art of proper group work management in their teachers training stint. Group work activities provide interesting and enjoyable lessons to students. The group work activities give students an opportunity to make decisions which are important 
in their everyday life. With proper planning, preparation and a positive attitude towards group work on the part of ESL teachers, group work can be a painless and enjoyable experience for both the teachers and students.

\section{References}

Blumenfeld, L. (1992). Effective Teaching in School. New York: Holt.

Doyle, W. (1986). Classroom Organization Management. New York: MacMillan.

Galton et al. (1980). Group Work in Primary School. London: Longman.

Good, T. et al. (1994). Looking in Classroom. London: Harper Collin Colledge Pub.

Jaccard, J., \& Becker, M. A. (1990). Statistics for Behavioral Science. California: Wadsworth Publishers.

Jacques, D. (1991). Learning in Groups. London: Kogan Page Ltd.

Kerry, T., \& Sands, M. K. (1982). Effective Teaching in Schools. England: Basil Blackwell Lt.

McNamara, K. (1994). Mix Ability Teaching. London: Croom Helm. Ltd.

Nunan, D. (1991). Language Teaching Methodology. New York: Prentice Hall.

Orstein, A. C., \& Thomas. (2000). Foundation of Education. Boston: Houghton Mifflin Co.

Richard, J. C., \& Nunan D. (1987). Second Language Teacher Education. Cambridge: Cambridge University Press.

Robiah Sidin. (1993). Classroom Management. Kuala Lumpur : Penerbitan Fajar Bakti.

Sellaodayan, G. (1988). The Influence of the Motivational Factors in the Achievement of English Language. Unpublished M.ED. practicum Report, USM.

Slavin, R. E. (1990). Learning to Co-operate. London: Plenum.

Stradling, \& Saunders. (1993). Classroom Management in Context. Toronto: Houghton Miffin Com. 